\title{
Studying the Economic, Socio-Cultural and Environmental Outcomes of Ecotourism on Local Communities Using SEM Model
}

\author{
Elmira Rostami ${ }^{1} \&$ Mozhgan Sabet Teimouri ${ }^{2}$ \\ ${ }^{1}$ Graduate Student of Tourism Management, Binaloud High Education Institute, Mashhad-Iran \\ ${ }^{2}$ Assistant Professor, Ph.D. of Ecology, Department of Tourism Management and Planning, Institute of Tourism \\ Research, ACECR, Khorasan Razavi Organization \\ Correspondence: Mozhgan Sabet Teimouri, Assistant Professor, Ph.D. of Ecology, Department of Tourism \\ Management and Planning, Institute of Tourism Research, ACECR, Khorasan Razavi Organization. E-mail: \\ ecotijdm@gmail.com
}

Received: March 16, 2019

Accepted: July 21, 2019

Online Published: July 26, 2019

doi:10.5539/mas.v13n8p48

URL: https://doi.org/10.5539/mas.v13n8p48

\begin{abstract}
In this paper the ecotourism development (ED) outcomes on economic (ECE), socio-cultural (SCE) and environmental (ENE) effects on local communities was studied. For this purpose, the structural equation model (SEM) model was used. For empirical data and case study, the Kang and Noghondar villages of Khorasan-e-Razavi province of Iran were selected. Results indicated that ecotourism development (ED) has positive significant effect at $1 \%$ on economic effects (ECE) of Kang and Noghondar villages. Also, if ED of Kang and Noghondar villages improve 1 unit, ECE will increase equal to 0.81 and 0.83 units, respectively. In addition, ecotourism development (ED) has negative significant effect at $1 \%$ on environmental effects (ENE) of Kang and Noghondar villages. Also, if ED of Kang and Noghondar villages improve 1 unit, ENE will decrease equal to 0.67 , and 0.69 units, respectively. Finally, ecotourism development (ED) has positive significant effect at $1 \%$ on socio-cultural effects (SCE) of Kang and Noghondar villages. Also, if ED of Kang and Noghondar villages improve 1 unit, SCE will decrease increase to 0.74 and 0.71 units, respectively.
\end{abstract}

Keywords: ecotourism, economic effects, socio-cultural effects, environmental effects, SEM model

\section{Introduction}

Ecotourism is one of the fastest growing sectors of sustainable tourism industry (UNEP, 2013), which focuses on wildlife conservation, environmental protection, poverty alleviation and economic development. There is no such universally accepted definition of ecotourism. It is differentiated from nature-based tourism as it helps in sustainable rural development and makes biodiversity conservation economically viable for local communities (Anup et al, 2015). On the other hand, ecotourism is a form of natural resource-based tourism that is educational, low-impact, none-consumptive, and locally oriented: local people must control the industry and receive the bulk of the benefits to ensure sustainable development (D'Angelo et al., 2010). Briefly, ecotourism can be conceptualized as any tourism program that is (a) nature based, (b) ecologically sustainable, (c) where education and interpretation is a major component and (d) where local people are benefited can be called ecotourism (Vishwanatha and Chandrashekara, 2014). In addition, as one of the world's largest economic sectors, travel and tourism creates jobs, drives exports, and generates prosperity across the world. In annual analysis of the global economic impact of travel and tourism, the sector is shown to account for $10.4 \%$ of global GDP and 313 million jobs, or 9.9\% of total employment, in 2017 (WTTC, 2018). Although, ecotourism has many economic advantages, but it may have some economic, socio-cultural and environmental disadvantages for local communications. On the other hand, tourism in Iran is diverse, providing a range of activities from hiking and skiing in the Alborz and Zagros mountains, to beach holidays by the Persian Gulf and the Caspian Sea. The Iranian government has been making concerted efforts to attract tourists to the various destinations in the country and arrivals have increased during the past few years. But according to WTTC (2018) annual report, the total contribution of travel and tourism to GDP of Iran is just USD30.7bn, 7.3\% of GDP and it totally supported $1,577,500$ jobs (6.1\% of total employment). Therefore, studying the various economic, socio-cultural and environmental outcomes of ecotourism on local communities, can contribute to better management of ecotourism in this area which it will carried out in this research with the case study of Kang and 
Noghondar villages of Khorasan-e-Razavi Province of Iran. The paper is organized as follows. Section 2 provides a survey of the literature on ecotourism. Section 3 describes our data set, and Section 4 presents the results of economic, socio-cultural and environmental outcomes of ecotourism on local communities using SEM model in Kang and Noghondar villages. Section 5 concludes.

\section{Literature Review}

Teresa and Martin (2007) studied international tourist arrivals to Balearic Islands from 14 major origin countries during 1991-2003. Applying the panel data, they found that after the terrorist attacks of 11 September 2001, international tourists have changed long-run for short-run destinations and destinations accessible by car were preferred over destinations that require air travel. McAleer and Min (2009) investigated international tourism demand of Japan to New Zealand and Taiwan. Results indicated that ARMAX model proves the theory of economics in which demand for international travel has a positive relationship with the income of tourist's native country. Kiper et al (2011) studied the ecotourism opportunities in Kiyiköy town of Turkey, the awareness of the local people and their role-expectations in this subject have been assessed and the perceptions of the local people towards the environmental, socio-cultural and economic effects of ecotourism have been examined. Results of factor analysis revealed that the area has significant ecotourism potential and the local people have a positive attitude towards ecotourism planning to be developed. Vishwanatha and Chandrashekara (2014) studied the perceptions of people, representing the host communities of ecotourism, on the socio-cultural impacts of ecotourism in the Kodagu district. Expert interviews have conducted to collect the information on socio-cultural impacts of ecotourism in the study area. The results have shown both the positive and negative impacts; however, there are positive impacts have strong in improving local economy, infrastructure service, children education, conservation and reduction of poverty. Li et al (2018) studied the economic impact of ecotourism in regional China with a focus on Yunnan and Sichuan provinces, which attract about 50 percent of the total number of tourists visiting China annually. Their analysis suggested that tourism significantly contributes to value added, output, income and employment generation in Yunnan and Sichuan provinces, although the level of contribution varies between the two provinces. Carvache-Franco et al (2019) analyzed the motivations and segmentation of the demand for ecotourism, using functional theory. Empirical analysis was carried out in Santay National Recreation Area, Morro Mangrove Wildlife Refuge, and Samanes National Recreation Area. Factorial analysis and non-hierarchical segmentation were applied to analyze the data. Results showed that there are several motivational dimensions in ecotourism, including self-development, interpersonal relationships and ego-defensive function, building personal relationships, escape reward, and nature appreciation.

\section{Materials and Method}

\subsection{Studied Area}

Kang and Noghondar villages are in Khorasan-e-Razavi province of Iran. Kang is estimated to be 3000 years old, which dates back to pre-Islamic time, studying the sacred books of Zoroastrianism reveals it to be even older (Public Relations Council of Torqabeh-Shandiz, 2015). Both villages are centered in mountains, rivers and beautiful perspectives. The climate of these two villages is a semi-arid climate based on the De Martonne classification (Raziei, 2017 and Kamyabi, 2015). The average annual temperature is 13 degrees Celsius, 80 days of freezing in the year and the number of sunny days per year is about 2900 hours for this study areas (Razavimet, 2019).

The Kang village is located at the end of the river valley's road, on the northeast slopes of the Binaloud mountain range. Kang is located 19 kilometers west of Torqabeh and 29 kilometers from Mashhad and is located at $36^{\circ}$ $19^{\prime} 18.9^{\prime \prime N} 59^{\circ} 13^{\prime 2} 1.9^{\prime \prime}$ E. Distance of Noghondar from Kang is about $9 \mathrm{~km}$ and Altitude of Noghondar is above 350 meters' sea level less than Kang (Google Map, 2019).

Figures 1, 2 and 3 illustrated the location of mentioned areas (Google Map, 2019): 


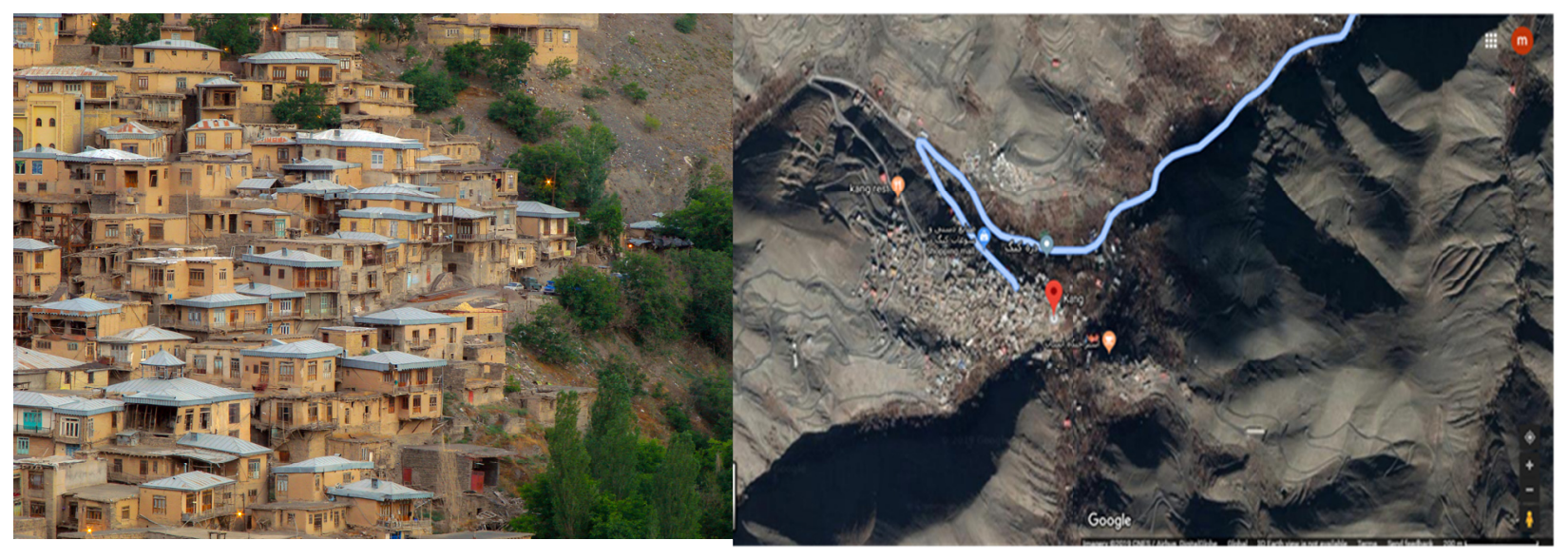

Figure 1. Knag village

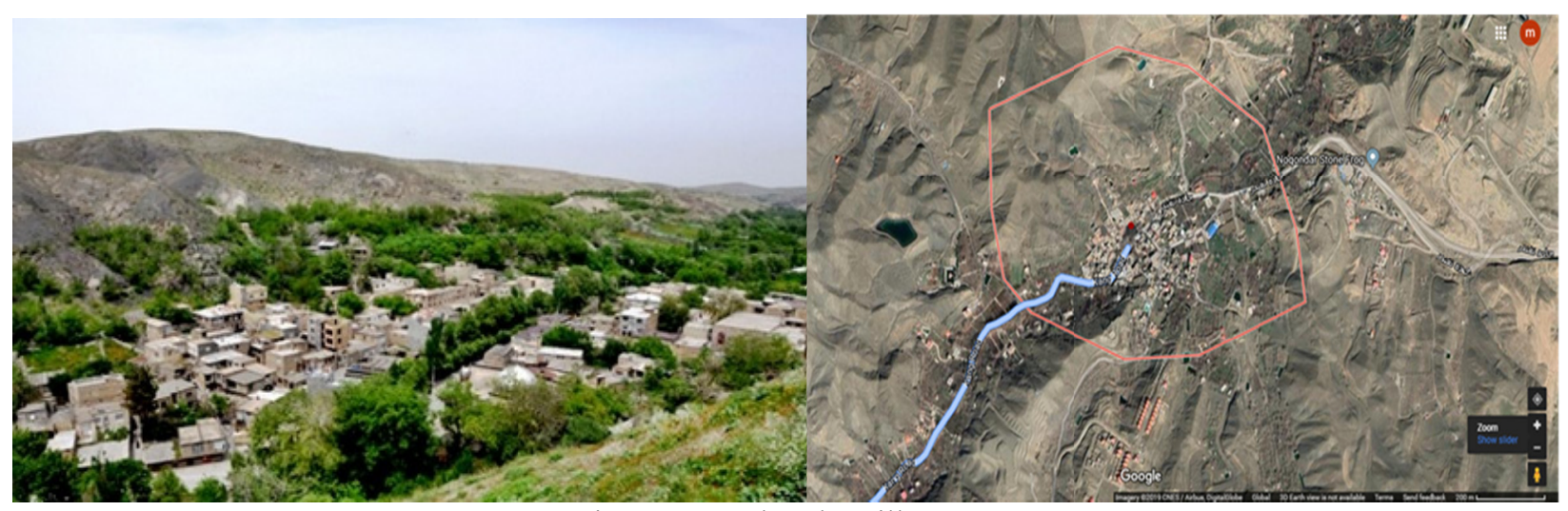

Figure 2. Noghondar village

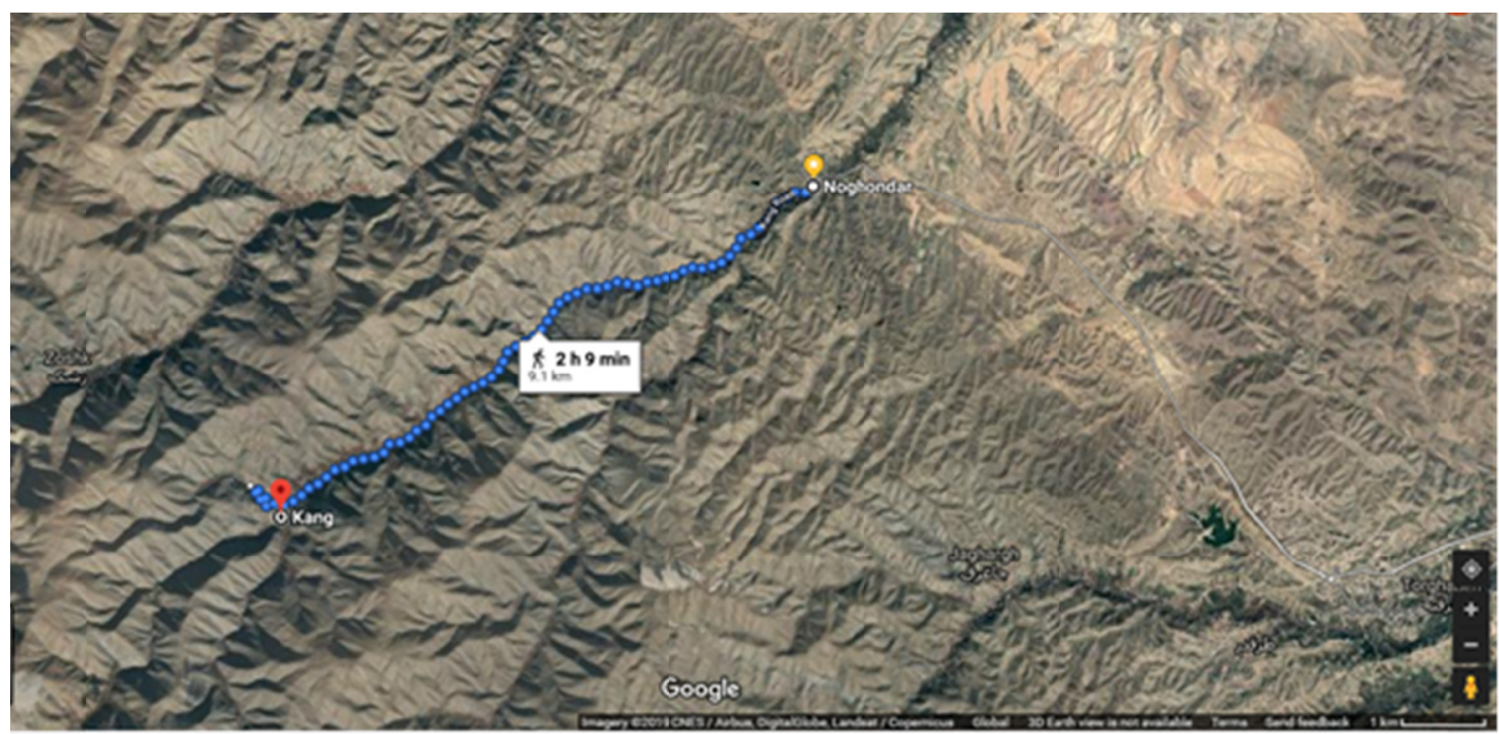

Figure 3. Location and distance of Noghondar and Kang Villages, (Satellite photography of google map, 2019) 


\subsection{Variables}

\section{- Independent variable:}

Ecotourism development which will measured using follows questions:

$\mathrm{X} 1 \quad$ Flood making and floodwater control

X2 Transportation infrastructures development

X3 Suitable path increasing

X4 Natural resources and national lands control

X5 Making secondary tourism attractions

X6 Historical context and cultural heritage protection

X7 Garbage gathering situation and public path cleanness

X8 Public health services situation

X9 Groceries, bakeries, restaurants, accommodations control

X10 Medical centers situation

X11 Security situation

X12 Education services and equipment of situation

\section{- Dependent variable:}

a) Economic effects which will measured using follows questions:

Y1 Making direct and indirect job opportunities

Y2 Income generating using entrance pay

Y3 Income generating using voucher delegation to private sector

Y4 Income generating using received donations for protecting animals and plants varieties

Y5 Foreign income generating from external visitors

Y6 Possibility of absorbing domestic and foreign investments

Y7 Contributing to local community development and economic inequalities justification

Y8 Local infrastructures development

Y9 Pressure on goods and services prices due to visitor's demand

b) Socio-cultural effects which will measured using follows questions:

Y10 Introducing local community to visitors

Y11 Notice to traditional arts and handicrafts

Y12 Making socio-cultural co-integration

Y13 Social inequalities reduction and social justice development

Y14 Immigration to city situation

Y15 Contribution of local peoples in decision making

Y16 Protecting from contribution of local peoples for introducing domestic culture to visitors

Y17 Local welfare situation

Y18 Effect of visitors on cultural authentic templates of local communities

Y19 Spurious jobs and beggary situation

c) Environmental effects which will measured using follows questions:

Y20 Contribution of local peoples and institutions from environment due to visitors' presence

Y21 Controlling the use of natural lands with judicial officers

Y22 Controlling jungle trees cutting and illegal hunting

Y23 Training and promoting environmental culture between visitors 
Y24 Public awareness and local community about environment protection

Y25 Natural environment destruction due to walking in woodlands

Y26 Effect of tourism activities such as: hunting, land use change, fire, off road and ...

Y27 Use of tourism equipment and resources status

Y28 Waste gathering and their healthy Landfill

Y29 Voice pollution situation

\subsection{Data Collection}

Statistical society of this research includes of whole residents of Kang $(\mathrm{N}=799)$ and Noghondar $(\mathrm{N}=855)$ villages. For determining the required sample, the random simple sampling method was used as follow:

$$
\begin{aligned}
& n=\frac{799 \times 1.96^{2} \times 0.5(1-0.5)}{799 \times 0.01^{2}+1.96^{2} \times 0.5(1-0.5)} \cong 86 \\
& n=\frac{855 \times 1.96^{2} \times 0.5(1-0.5)}{855 \times 0.01^{2}+1.96^{2} \times 0.5(1-0.5)} \cong 86
\end{aligned}
$$

Therefore, designed questionnaires distributed between 86 residents of mentioned areas.

\subsection{Model}

In this research the structural equation model (SEM) model will apply for studying the effect of ecotourism development on economic, socio-cultural and environmental situation of Kang and Noghondar villages. SEM is a multivariable robust technique which is developed form of general linear model and provides the possibility of testing regression equations simultaneously. A suggested approach to SEM analysis proceeds through the figure 4.

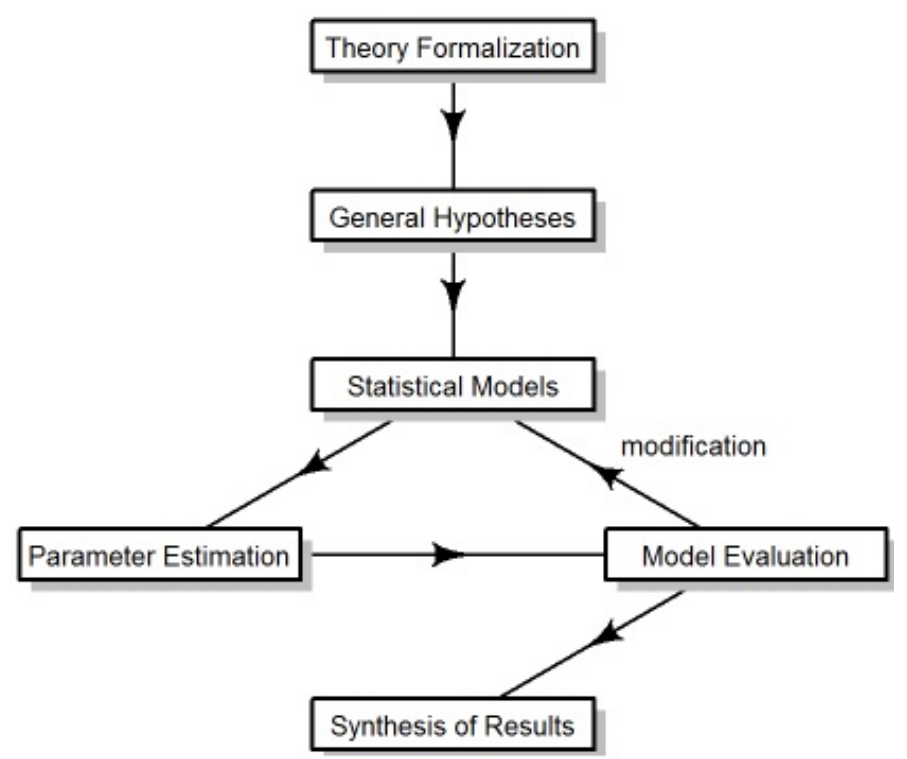

Figure 4. The process of SEM technique (MacCallum \& Austin, 2000).

On the other word SEM is a technique for representing, estimating, and testing a network of relationships between variables. However, SEM requires specification of a model based on theory. Therefore, the researcher should be reviewing the related literatures in order to support the specification of predesigned model.

\section{Results}

\subsection{Sample Description}

Brief properties of studied sample of Kang and Noghondar residents have been presented as follow: 
Table 1. Properties of studied sample of Kang $(\mathrm{K})$ and Noghondar $(\mathrm{N})$ residents

\begin{tabular}{|c|c|c|c|c|c|c|c|c|c|}
\hline \multirow{2}{*}{ Gender } & \multicolumn{2}{|c|}{ Frequency } & \multicolumn{2}{|c|}{ Percentage } & \multirow{2}{*}{ Marriage status } & \multicolumn{2}{|c|}{ Frequency } & \multicolumn{2}{|c|}{ Percentage } \\
\hline & $K$ & $N$ & $K$ & $N$ & & $K$ & $N$ & $K$ & $N$ \\
\hline Male & 55 & 60 & 64 & 70 & Married & 78 & 77 & 91 & 90 \\
\hline Female & 31 & 26 & 36 & 30 & Single & 8 & 9 & 9 & 10 \\
\hline Total & 86 & 86 & 100 & 100 & Total & 86 & 86 & 100 & 100 \\
\hline \multirow{2}{*}{ Age (year) } & \multicolumn{2}{|c|}{ Frequency } & \multicolumn{2}{|c|}{ Percentage } & \multirow{2}{*}{ Education } & \multicolumn{2}{|c|}{ Frequency } & \multicolumn{2}{|c|}{ Percentage } \\
\hline & $K$ & $N$ & $K$ & $N$ & & $K$ & $N$ & $K$ & $N$ \\
\hline Below 30 & 10 & 11 & 11.63 & 12.79 & $\begin{array}{l}\text { Diploma and under } \\
\text { diploma }\end{array}$ & 35 & 36 & 40.70 & 41.86 \\
\hline $30-40$ & 17 & 17 & 19.77 & 19.77 & Upper diploma & 30 & 29 & 34.88 & 33.72 \\
\hline $40-50$ & 26 & 26 & 30.23 & 30.23 & Bachelor & 20 & 19 & 23.26 & 22.09 \\
\hline Upper 50 & 33 & 32 & 38.37 & 37.21 & Master and upper & 2 & 2 & 2.33 & 2.33 \\
\hline Total & 86 & 86 & 100.00 & 100.00 & Total & 86 & 86 & 100.00 & 100.00 \\
\hline \multirow{2}{*}{$\begin{array}{l}\text { Household } \\
\text { dimension }\end{array}$} & \multicolumn{2}{|c|}{ Frequency } & \multicolumn{2}{|c|}{ Percentage } & Monthly income (million & \multicolumn{2}{|c|}{ Frequency } & \multicolumn{2}{|c|}{ Percentage } \\
\hline & $K$ & $N$ & $K$ & $N$ & $R L S)$ & $K$ & $N$ & $K$ & $N$ \\
\hline 1 & 9 & 9 & 10.47 & 10.47 & Under 20 & 33 & 31 & 38.37 & 36.05 \\
\hline 2 & 11 & 12 & 12.79 & 13.95 & 20-30 & 27 & 26 & 31.40 & 30.23 \\
\hline 3 & 15 & 14 & 17.44 & 16.28 & $30-50$ & 18 & 19 & 20.93 & 22.09 \\
\hline 4 & 21 & 19 & 24.42 & 22.09 & $50-100$ & 8 & 10 & 9.30 & 11.63 \\
\hline 5 and more & 30 & 32 & 34.88 & 37.21 & Upper 100 & 0 & 0 & 0.00 & 0.00 \\
\hline Total & 86 & 86 & 100.00 & 100.00 & Total & 86 & 86 & 100.00 & 100.00 \\
\hline \multirow{2}{*}{ Job type } & \multicolumn{2}{|c|}{ Frequency } & \multicolumn{2}{|c|}{ Percentage } & \multirow{2}{*}{ Contribution } & \multicolumn{2}{|c|}{ Frequency } & \multicolumn{2}{|c|}{ Percentage } \\
\hline & $K$ & $N$ & $K$ & $N$ & & $K$ & $N$ & $K$ & $N$ \\
\hline Farming & 4 & 3 & 4.65 & 3.49 & Cocking & 15 & 13 & 17.44 & 15.12 \\
\hline Livestock & 15 & 17 & 17.44 & 19.77 & Baking bread & 23 & 25 & 26.74 & 29.07 \\
\hline Horticulture & 38 & 35 & 44.19 & 40.70 & Cleaning & 5 & 7 & 5.81 & 8.14 \\
\hline Handicraft & 19 & 20 & 22.09 & 23.26 & Handicraft & 12 & 11 & 13.95 & 12.79 \\
\hline Housewife & 10 & 11 & 11.63 & 12.79 & Agriculture harvests & 31 & 30 & 36.05 & 34.88 \\
\hline Total & 86 & 86 & 100.00 & 100.00 & Total & 86 & 86 & 100.00 & 100.00 \\
\hline
\end{tabular}

Resource: research findings

\subsection{SEM Model Specification}

In order to analyze the effect of ecotourism development (ED) on economic effects (ECE), socio-cultural effects (SCE) and environmental (ENE) effects of Kang and Noghondar villages, the SEM model was applied. Figures 5 and 6 illustrates the results of SEM model specification using smart PLS software: 


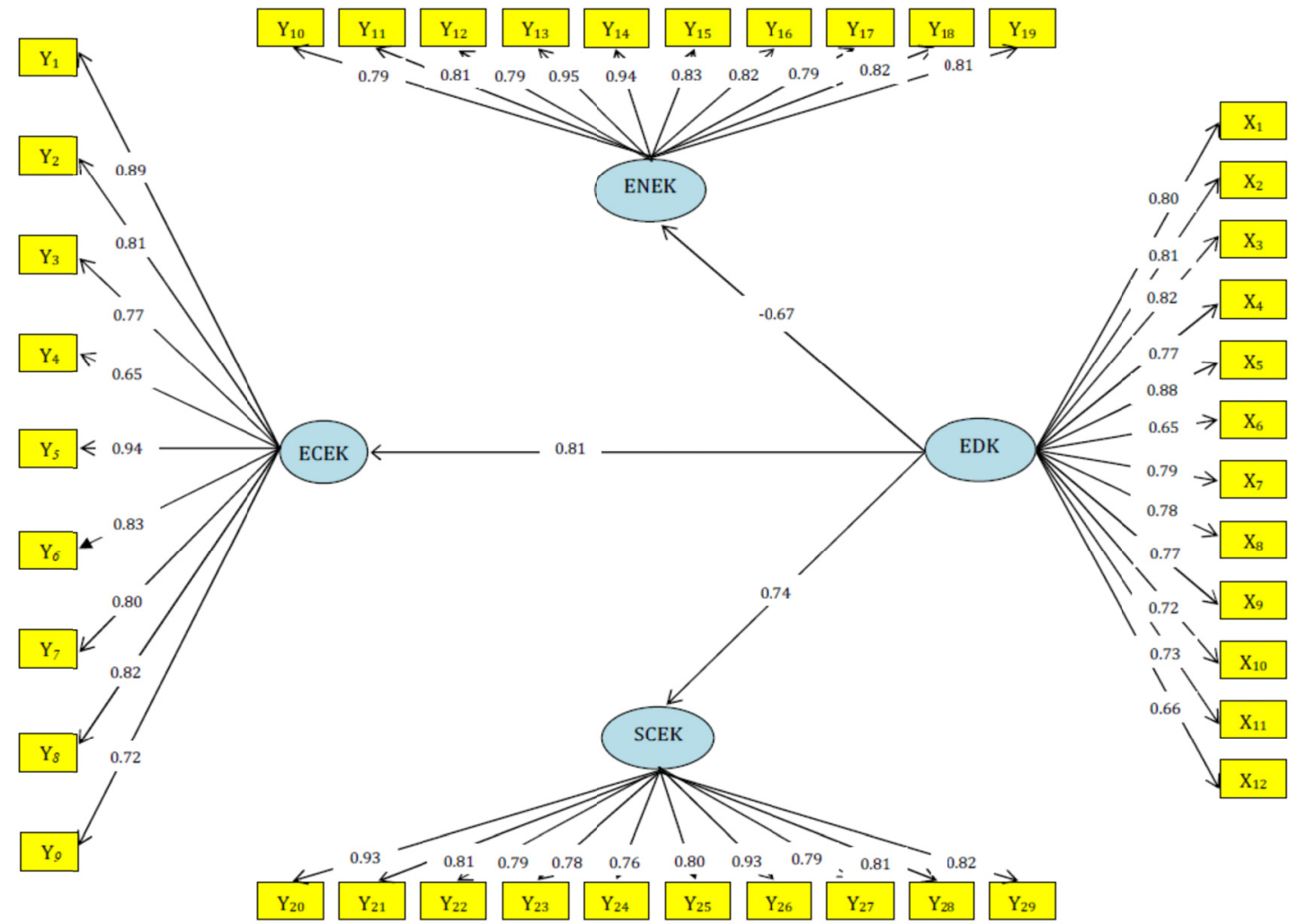

Figure 5. Results of SEM specification for Kang (K) village

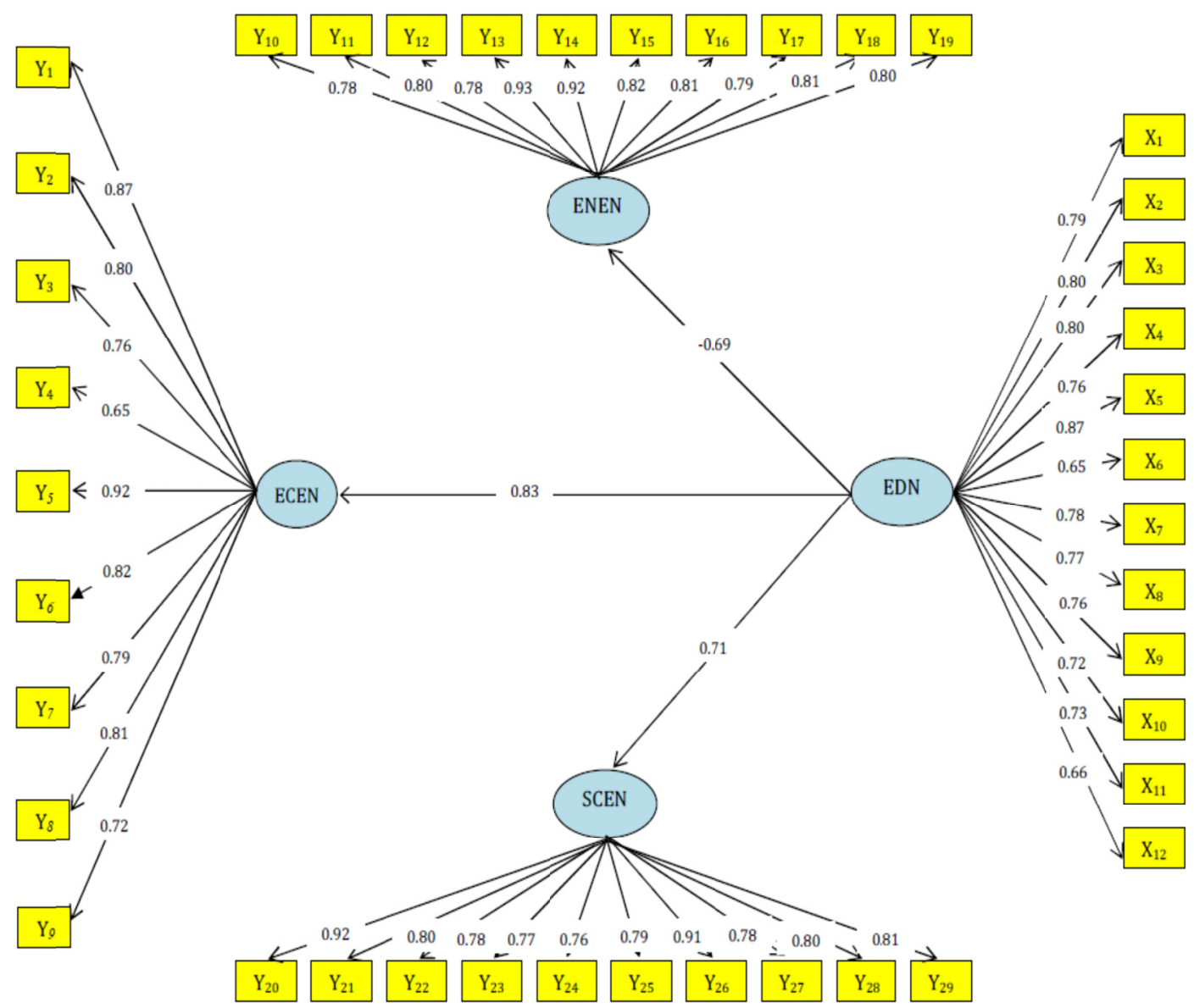

Figure 6. Results of SEM specification for Noghondar (N) village 
According to above SEM specifications below findings are concluded:

Table 2. Variables relationships

\begin{tabular}{|c|c|c|c|c|c|c|}
\hline \multirow{2}{*}{ Path } & \multicolumn{2}{|c|}{ Coefficient } & \multicolumn{2}{|c|}{ t Statistic } & \multicolumn{2}{|c|}{ P-value } \\
\hline & $K$ & $N$ & $K$ & $N$ & K & $N$ \\
\hline $\mathrm{ED} \rightarrow \mathrm{ECE}$ & $\gamma_{1}=0.81$ & $\gamma_{1}=0.83$ & 4.22 & 4.36 & $0.0000^{* * *}$ & $0.0000^{* * *}$ \\
\hline $\mathrm{ED} \rightarrow \mathrm{ENE}$ & $\gamma_{2}=-0.67$ & $\gamma_{2}=-0.69$ & -3.67 & -3.75 & $0.0000^{* * *}$ & $0.0000^{* * *}$ \\
\hline $\mathrm{ED} \rightarrow \mathrm{SCE}$ & $\gamma_{3}=0.74$ & $\gamma_{3}=0.71$ & 2.83 & 2.77 & $0.0046^{* * *}$ & $0.0056^{* * *}$ \\
\hline
\end{tabular}

According to above results of SEM model specification, ecotourism development (ED) has positive significant effect at $1 \%$ on economic effects (ECE) of Kang village (K). Also, if ED of Kang village improves 1 unit, ECE will increase equal to 0.81 units. In addition, ecotourism development (ED) has negative significant effect at $1 \%$ on environmental effects (ENE) of Kang village (K). Also, if ED of Kang village improves 1 unit, ENE will decrease equal to 0.67 units. Ecotourism development (ED) has positive significant effect at $1 \%$ on socio-cultural effects (SCE) of Kang village (K). Also, if ED of Kang village improves 1 unit, SCE will increase equal to 0.74 units.

On the other hand, ecotourism development (ED) has positive significant effect at $1 \%$ on economic effects (ECE) of Noghondar village (N). Also, if ED of Noghondar village improves 1 unit, ECE will increase equal to 0.83 units. In addition, ecotourism development (ED) has negative significant effect at $1 \%$ on environmental effects (ENE) of Noghondar village (N). Also, if ED of Noghondar village improves 1 unit, ENE will decrease equal to 0.69 units. Finally, ecotourism development (ED) has positive significant effect at $1 \%$ on socio-cultural effects (SCE) of Noghondar village $(\mathrm{N})$. Also, if ED of Noghondar village improves 1 unit, SCE will increase equal to 0.71 units.

\section{Summary and Conclusion}

In this research the ecotourism development outcomes on economic, socio-cultural and environmental effects on local communities was studied using SEM model with the case study of Kang and Noghondar villages of Khorasan-e-Razavi province of Iran. Results indicated that ecotourism development (ED) has positive significant effect at $1 \%$ on economic effects (ECE) of Kang and Noghondar villages. Also, if ED of Kang and Noghondar villages improve 1 unit, ECE will increase equal to 0.81 and 0.83 units, respectively. In addition, ecotourism development (ED) has negative significant effect at $1 \%$ on environmental effects (ENE) of Kang and Noghondar villages. Also, if ED of Kang and Noghondar villages improve 1 unit, ENE will decrease equal to 0.67, and 0.69 units, respectively. Finally, ecotourism development (ED) has positive significant effect at $1 \%$ on socio-cultural effects (SCE) of Kang and Noghondar villages. Also, if ED of Kang and Noghondar villages improve 1 unit, SCE will decrease increase to 0.74 and 0.71 units, respectively.

According to positive effects of ecotourism development on economic and socio-cultural status and its negative effect on environmental status of studied local communities it is suggestible that government authorities implement the assessed factors in Kang and Noghondar villages in order to increase the positive and alleviate the negative effects of ecotourism on local communities.

It seems that the best way to realize sustainable tourism development is to use evaluation models and then provide the best operational plan for the purposes of community participation and environmental protection based on the results of the model.

\section{References}

Anup, KC, Rijal, K. \& Sapkota, RP. (2015). Role of ecotourism in environmental conservation and socioeconomic development in Annapurna conservation area, Nepal. International Journal of Sustainable Development \& World Ecology, 22(3). 251-258. https://doi.org/10.1080/13504509.2015.1005721

Carvache-Franco, M., Segarra-Oña, M. \& Carrascosa-López, C. (2019). Segmentation by Motivation in Ecotourism: Application to Protected Areas in Guayas, Ecuador, Sustainability 2019, 11, 240, https://doi.org/10.3390/su11010240

D’Angelo, R., Sachasiri, T., Vaccaro, N., Welie, MV., Vargas, A. \& Yongsanguanchai, N. (2010). Post-tsunami ecotourism development: solutions for the laem khruat village. 90. Retriewed 14 October 2010 from: 
www.wpi.edu/Pubs/E-project/Available. https://www.razavimet.ir/fa/node/38

Kamyabi, S. (2016). Adaptation of the climatic classification system to the architecture of the cities of Khorasan Razavi, Geographic Quarterly of the Territory, 15(50).

Kiper, T., Ozdemir, G. \& Saglam, C. (2011). Environmental, socio-cultural and economical effects of ecotourism perceived by the local people in the northwestern Turkey: Kiyiky case, Scientific research and essays, 6(19). 4009-4020. https://doi.org/10.5897/SRE10.1059

Li Y. Sun, Q. Bandara, Y. Sharma, K. Hicks \& J. Basu, P. K. (2018). The Economic Impact of Ecotourism on Regional China: Further Evidence from Yunnan and Sichuan Provinces, Global Business Review, 19(3). 533-542. https://doi.org/10.1177/0972150917713887

McAleer, M. \& Min, C.H. (2009). ARMAX modeling of international tourism demand. Mathematics and Computers in Simulation, 79(9). 2879-2888. https://doi.org/10.1016/j.matcom.2008.08.010

MacCallum, R. C. \& Austin, J. T. (2000). Applications of structural equation modeling in psychological research. Annual Review of Psychology, 51, 201-226. https://doi.org/10.1146/annurev.psych.51.1.201

Public Relations Council of Torqabeh Shandiz (2015).

Raziei, T. (2017). An outlook on the Iranian Köppen-Geiger climate zones in the 21st century, Iranian Journal of Geophysics, 11(1), 6.

UNEP, Tourism: Trends. (2013). Challenges and Opportunities, in Green Economy and Trade. United Nations Environment Program, 259-291.

Vishwanatha, S. \& Chandrashekara, B. (2014). An Analysis of Socio-Cultural Impacts of Ecotourism in Kodagu District, American Journal of Research Communication, 2(7). 135-147.

World Travel and Tourism Council (WTTC) annual report. (2018).

\section{Copyrights}

Copyright for this article is retained by the author(s), with first publication rights granted to the journal.

This is an open-access article distributed under the terms and conditions of the Creative Commons Attribution license (http://creativecommons.org/licenses/by/4.0/). 